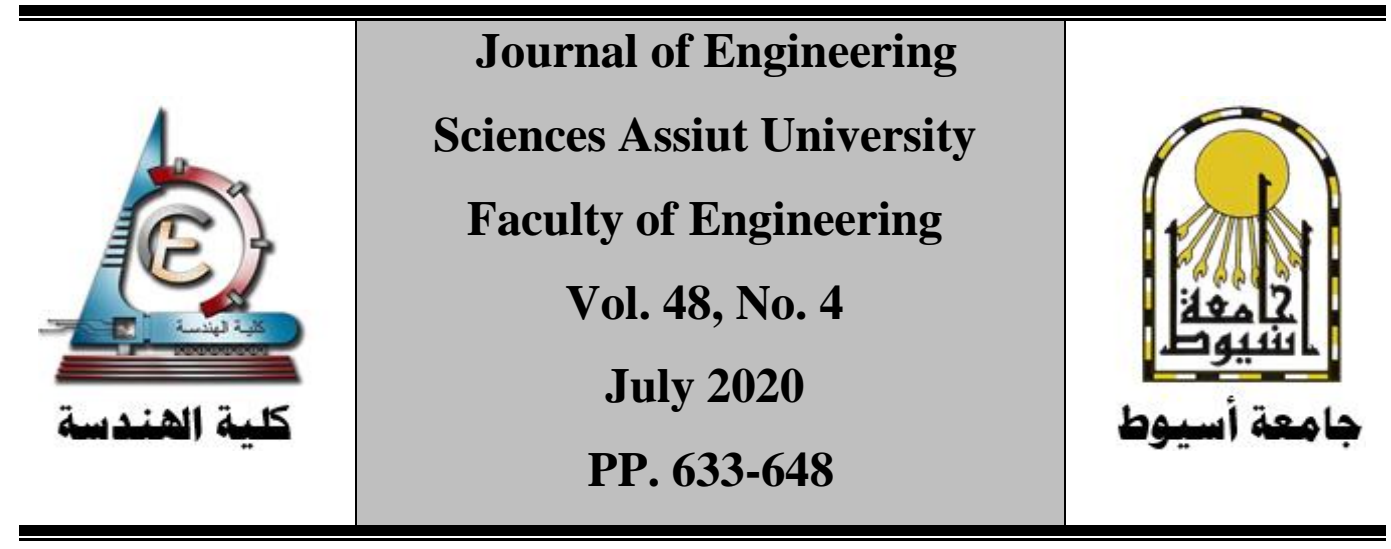

\title{
TOWARDS ZERO-ENERGY BUILDINGS IN MANSOURA UNIVERSITY
}

\section{Basma G. A.-F El Awadi, Mohanad A. M. Fouda, Alaa S. El Aishy}

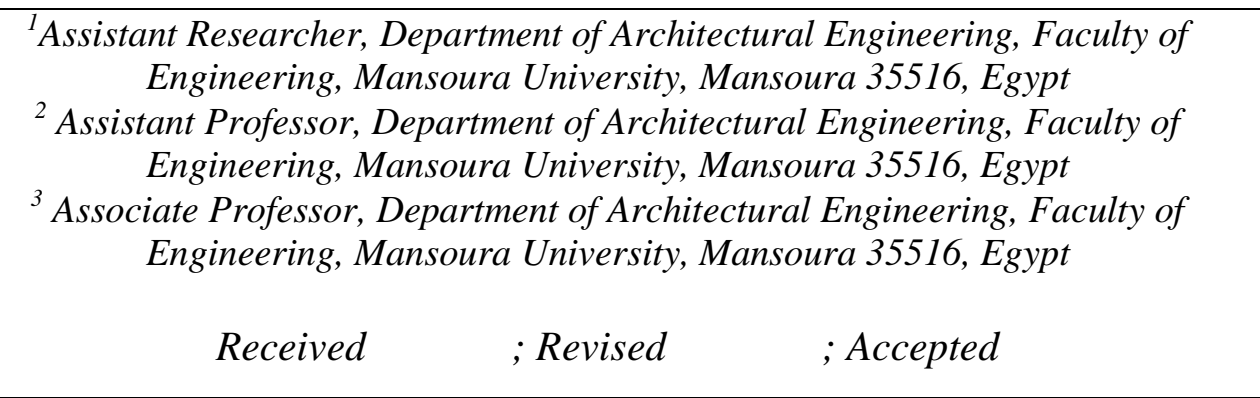

\begin{abstract}
The paper introduces the feasibility of achieving zero energy on University buildings in Egypt through retrofitting three buildings affiliated to Faculty of Engineering, Mansoura University (two of them are existing buildings and the third one is under construction). The paper used the design Builder software, that was used to calculate energy consumption for each building and then to upgrade them. Also, a simulation tool was used to optimize the electricity consumption of the building that is under construction through getting the optimal cooling system. It is evident from the results that retrofitting decreases energy consumption by $50-90 \%$ with the possibility of achieving zero energy by using renewable energy sources such as solar cells.
\end{abstract}

KEYWORDS: ZEB; ZEB in university; Renewable energy; Solar energy.

HVAC

LEED

HRV
Heating, Ventilating, and Air

Conditioning

Leadership in Energy and

Environmental Design Heat recovery ventilation
NOMENCLATURE

PV Photovoltaics

ZEB Zero Energy Building

Nat vent Natural ventilation 


\section{Introduction}

The concept of Zero Energy Building (ZEB) has gained wide international attention during last few years and is now seen as the future target for the design of buildings. In the last decade there has been a major focus on net-zero energy buildings from number of different organizations such as The European Energy Performance of Buildings Directive (EPBD). It has published a recast on 2010 that defines some of its goals including that by end of 2020 all new buildings must be nearly zero-energy buildings ZEB.[1] Since Nov, 2018, The U.S. Green Building Council has developed LEED Zero, a complement to LEED that verifies the achievement of net zero through zero carbon and resources (water -energy - waste). [2] The general pathway to achieve ZEB consists of two steps: first, reduce energy demand by means of energy efficiency measures. Second, generate electricity through renewable energy to equal or exceed its annual energy use [3]. There are some facts about the energy consumption in Egypt. For example, electricity generation has increased by $500 \%$ during the period 1982-2005 from nearly 22 terawatt hours (TWH) to $108.4(\mathrm{TWH})$ at an average annual growth rate of 6.9\%.[4] Because of this reason, a techniques like ZEB must be used to help in reducing energy consumption and reduce dependency on non-renewable energy resources.

The ZEB solution seems to be fit perfectly for the energy problem in Egypt however there is a small number of researches about that subject. Recently published studies have started to focus on ZEB. Reda et al. (2015), have Designed a very low energy residential building, with regard to the climate at New Borg El Arab City (NBC). Remarkable results were achieved in ZEB using a PV system size that is within the range of the power capacities conventionally utilized in the residential sector of the Mediterranean countries. [5] Albadry (2016), converted existing residential buildings in Cairo to ZEB buildings. He proved that an existing residential building can generate an amount of solar energy equivalent to the amount of energy consumed within a year. [6] Abolsaad (2018) designed a zero-energy house unite in the desert climate city, Alfilaria. This research focuses on presenting zero energy building design as an approach for sustainable urban development in the Egyptian desert. The research has shown a potential for achieving zero energy buildings locally through the application of the proposed approach. [7] As shown from previous researches, despite ZEB concept can be achieved in Egypt through energy efficiency measures and renewable energy, they focused on residential section only. Universities in Egypt also consume a lot of energy. A large proportion of existing educational buildings in Egyptian campuses are not energy efficient and are liable to the loss and gain of heat more aggressively. [8]. The aim of this research is to determine the ability of 
achieving ZEB on Egyptian universities. It is clear from previous studies that, university educational building in different climatic regions can achieve ZEB. For example, the BCA academy in South-east Asia was retrofitted from an existing to be ZEB [9]. Also, the same for Osaka University hall in Japan [10].

\section{Case Studies}

The study will be applied to three buildings belonging to the Faculty of Engineering, Mansoura University in Egypt. The case studies are three different educational buildings. They are close to each other in site which will help us to utilize the excess of electrical energy which produced by PV solar cells especially, for case (2) where, photo Voltic solar cells can be placed only on small portions of the roof which will affect the achieving of ZEB. The layout of our three case studies, orientation and buildings elevations are shown in [Figure-1] and Table (1). In case of case (3), it is under construction so, the lightening system and cooling system will be assumed.

\section{Methodology}

The first step of retrofitting an existing building is basically the building performance analysis, because this will define the amount of renovation that the building needs and identifies the areas of inefficiency. Then, the research will propose some changes to enhance the energy performance using market available products and decrease the amount of energy needed to the minimum. Based on the climate data analysis and software modeling, the final step would be adding the suitable energy renewable energy resource. The scope of the study will cover one type of renewable energy resources: solar PV panels, not only because solar energy represents the most abundant resource of renewable energy in Egypt but also, it's the easiest energy resource type to be used. The methodology was summarized in [Fig.2].

\subsection{Step (1) [Building performance analysis]}

The performance analysis of the building was done using Design Builder software (version 6.1.3) The data shown in Table (1) will be the input for the program as shown in [Figure- ${ }^{r}$ ]. Using simple HVAC tool which depending on the activity for each zone, the calculation of total energy, solar gains and cooling loads for each building will be done. By using simulation tool in design builder, the results for the three cases are shown in Table (2). The cooling loads 
for case (1) is $52 \%$, case (2) is $57 \%$ and case (3) is $50 \%$ from total consumption in year. It is clear from results that, the highest consumption is from April to September (summer months).

Table.1. Case studies

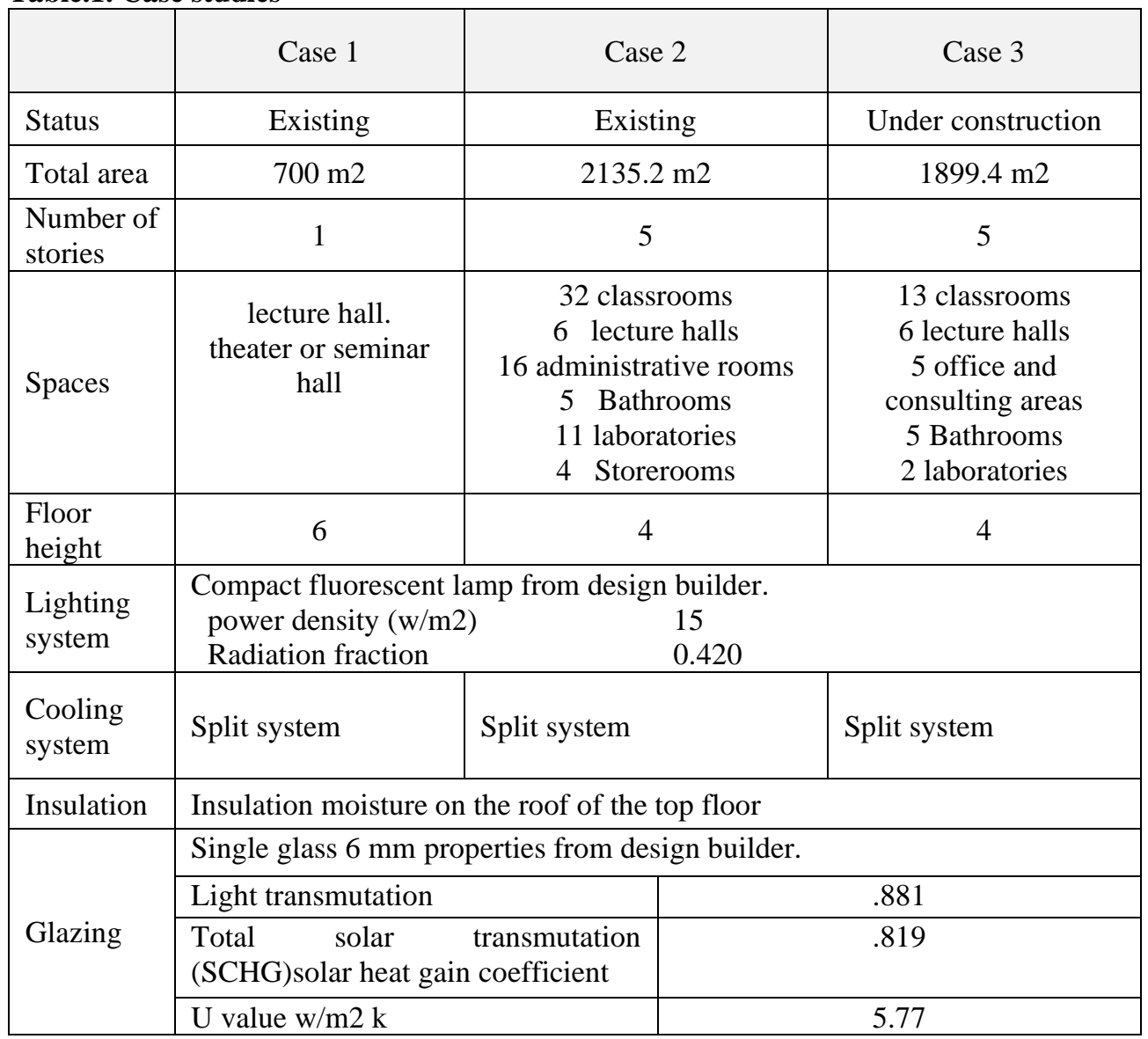

Table.2. Simulation results for three cases before upgrading

\begin{tabular}{|l|l|l|l|l|l|l|}
\hline MWh/y & lighting & cooling & $\begin{array}{l}\text { Total } \\
\text { consumption }\end{array}$ & $\begin{array}{l}\text { Solar } \\
\text { gains } \\
\text { wall }\end{array}$ & $\begin{array}{l}\text { Solar } \\
\text { gains } \\
\text { roof }\end{array}$ & $\begin{array}{l}\text { Solar gains } \\
\text { windows }\end{array}$ \\
\hline case 1 & 23.857 & 21.789 & 45.646 & 75.507 & 13.497 & 40.032 \\
\hline case 2 & 384 & 368.5 & 857.7 & 134 & 26.4 & 288 \\
\hline case 3 & 463.70 & 538 & 1079.30 & 36.1 & 105 & 1204 \\
\hline
\end{tabular}




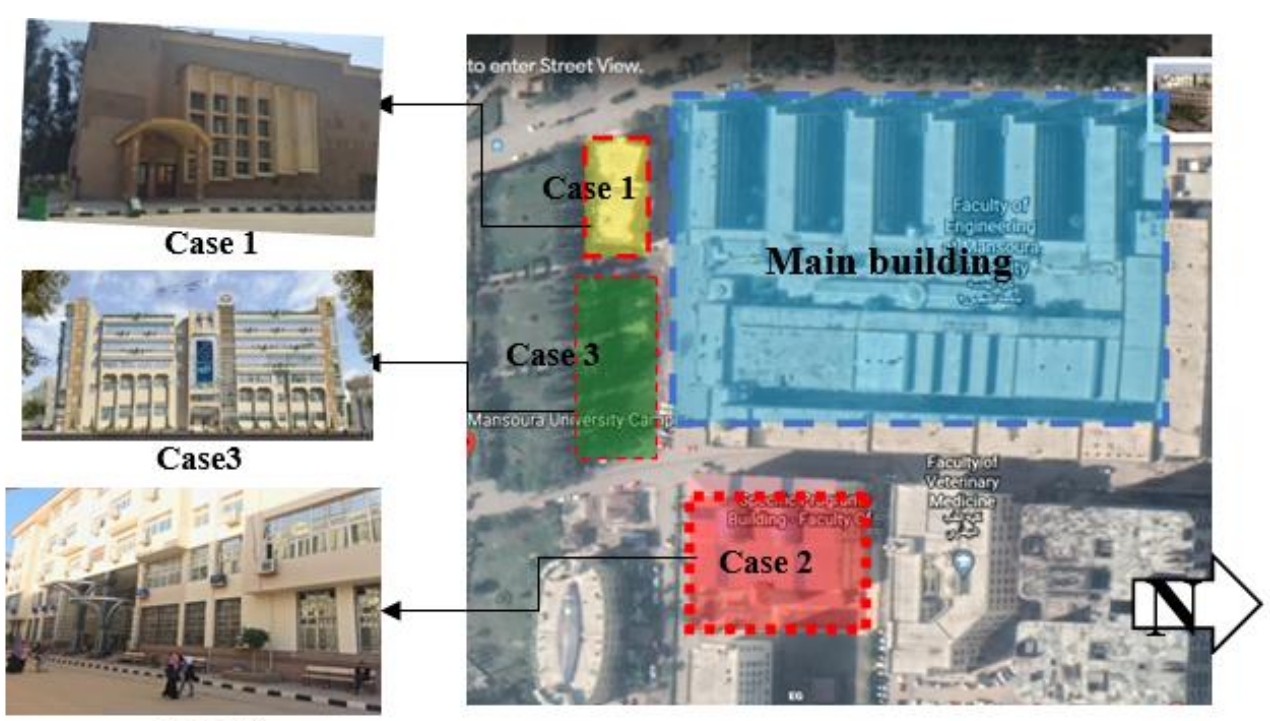

Case 2

Fig.1. Layout of case studies

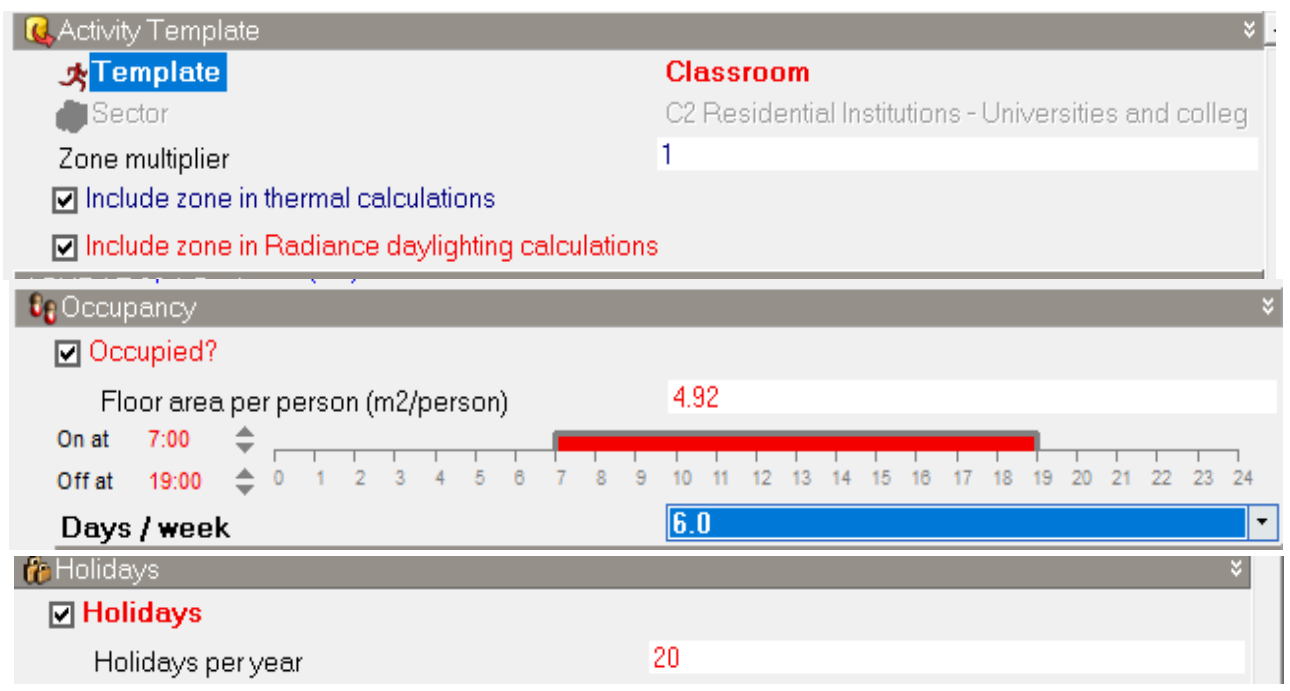

Fig.2. Main steps of the methodology

Fig.3. The input data of activity template in design builder

\subsection{Concrete Model: Step (2) [Determination of suitable retrofit technology]}

The highest consumption of electricity is due to cooling as shown from building performance analysis. For getting the lowest electricity consumption there are a lot of goals that must be achieved:

- Reducing cooling loads through efficient air conditioning system. 
- Decreasing solar gains through insulation of walls, roofs, and shading.

- Increasing natural lighting through changing type of glass.

- All the above goals will be achieved through the following retrofits.

\subsubsection{Insulation of walls and roof}

All three cases are only insulated by insulation moisture on the roof of the top floor. Therefore, walls and roofs must be insulated with thermal insulation to reduce thermal gains. The most common insulation material that can be applied to existing building for walls \& roofs in Egypt is the traditional foam sheets as shown on Table (3). [11]

Table.3. Thermal insulation properties upgrading case studies. [11]

\begin{tabular}{|c|c|c|c|}
\hline & Thickness $(\mathbf{m})$ & $\begin{array}{c}\text { Thermal Conductivity } \\
\left(\mathbf{W} / \mathbf{m}^{\circ} \mathbf{C}\right)\end{array}$ & $\begin{array}{c}\text { Coast Per area } \\
\text { EGP/ m2 }\end{array}$ \\
\hline $\begin{array}{c}\text { XPS (extruded } \\
\text { polystyrene) }\end{array}$ & 0.03 & 0.036 & 47.348 \\
\hline
\end{tabular}

\subsubsection{Windows retrofits}

All cases use single glazing type which increase solar thermal gains. From previous studies it was found that daylighting is the most effective passive solar strategy which is one of the significant uses of electricity, but also reduces the need for cooling when light but not heat is desired. The best types of glass to reduce thermal gain is tribble glazing with LOE coating, but the available glass in Egypt is Double Glass with LOE coating which will be used. Table (4) shows the properties of the glass.[12]

Table.4. (Dbl LoE 6mm) properties from design builder

\begin{tabular}{|c|c|}
\hline Light transmutation & .745 \\
\hline $\begin{array}{c}\text { Total solar transmutation }(\mathbf{S C H G}) \text { solar heat } \\
\text { gain coefficient }\end{array}$ & .568 \\
\hline U value (w/m $\mathbf{~} \mathbf{~ k )}$ & 1.493 \\
\hline Cost per area $\mathbf{E G P} / \mathbf{m}^{\mathbf{2}}$ & 1704.5 \\
\hline
\end{tabular}

\subsubsection{Shading}

The goal of shading design is to keep the sun out. The shading will be applied through fixed exterior shading (1m over hangs on South, east, west and $1 \mathrm{~m}$ Vertical fin on North elevations). [12]

\subsubsection{Efficient lighting}

Many case study buildings deploy efficient lamps based on LED lighting. These light source technologies are mature and very common in the market so for all case studies, led lighting with linear control will be used. Table (5) shows the properties of led lightening. [13] 
Table.5 properties of led lighting from design builder. [Source (researcher)]

\begin{tabular}{|l|l|}
\hline LED power density (w/m2) & 7.5 \\
\hline Radiation fraction & 0.42 \\
\hline Cost per area EGP/ m2 & 946.9 \\
\hline
\end{tabular}

\subsubsection{HVAC system}

Table (6) shows the cooling system before and after upgrading. For case (3), the cooling system will be designed as follows as the building is under construction. The optimization tool in design builder was used to choose the optimal design.

Table.6. Cooling system before and after upgrading for each case.

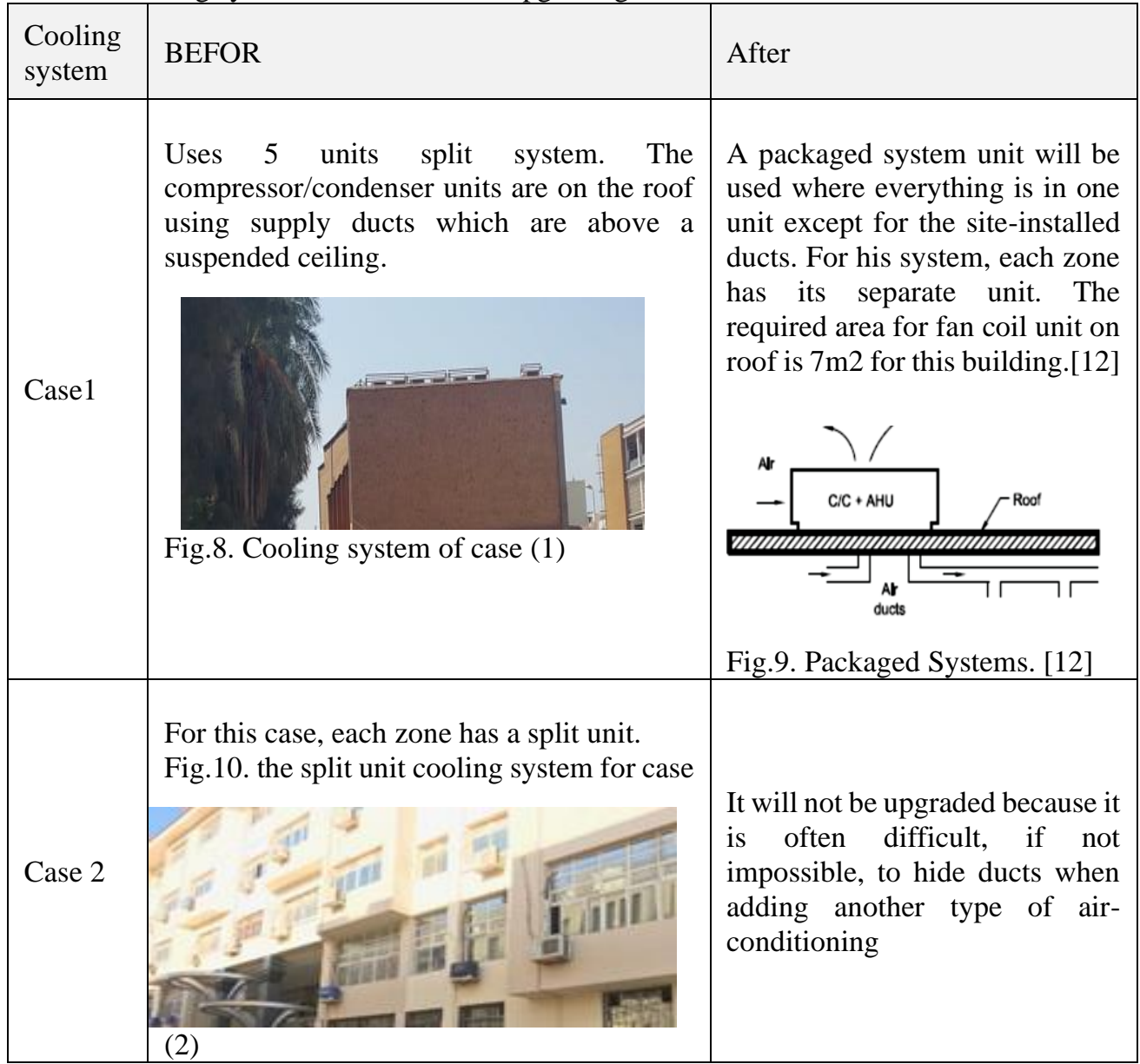


Objective: Multi objectives (less cooling electricity-less discomfort hours-less cost).

Design variables: Site orientation and cooling system which are used in worldwide ZEB [13] (air cooled chiller - ground heat exchanger-cooled beams with displacement vent). See [Fig -4].

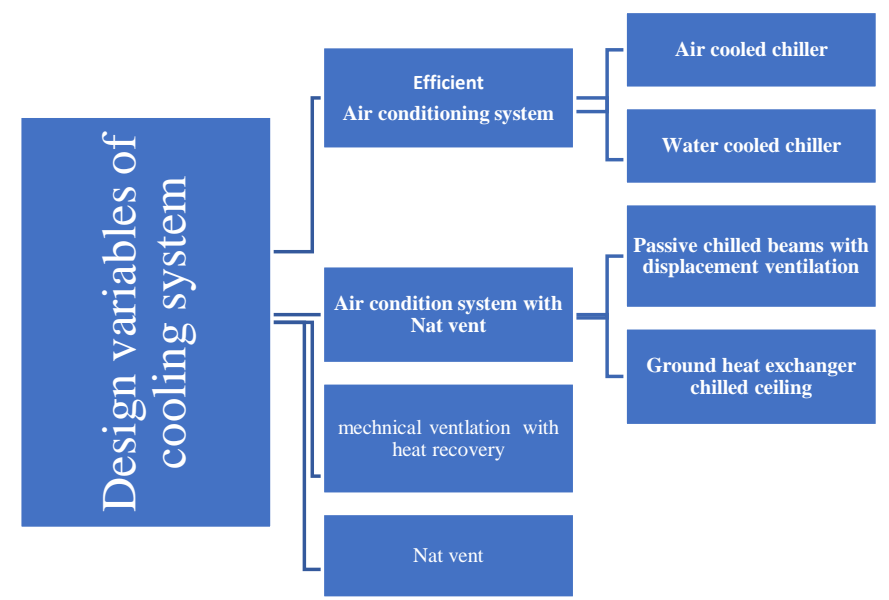

Fig.4. Design variables for cooling system optimization of case (3). [Source (researcher)]

\subsection{Step (3) [Renewable energy]}

As mentioned earlier, the solar energy will be used as the renewable energy source because of its availability and easy of application. This solar energy will be used through PV system. The steps of PV syst. program application will be as follows:

Project data: Define the geographic location (Mansoura city) and meteorological of the project site is acquired from version (PVsyst 6.8.1).

Energy Supply system: Using on-grid system which use Renewable energy (RE) sources available at the building site and connected to its electricity gridtied.

Direction and position: The best position is to direct the solar panels to the south at an angle of 300 and the type of panels is fixed. See [Fig.5].

Choosing the total available area for each building through PVsyst as shown in [Fig.6].

Solar cells type: Monocrystalline solar type panels will be used. This type has the highest efficiency rates since they are made out of the highest-grade silicon. This type also, requires the least amount of space compared to any other types and live the longest time (25-year).[14]

The specifications for selected Solar cells type are: 
Model: mono LG 300 A1C-B3 AC MODULE 208V.

Model area: $1.6 \mathrm{~m} 2$.

Solar cells cost: 9 pound/ Watt \& 1 Cells cost 2700 EGP.[15]

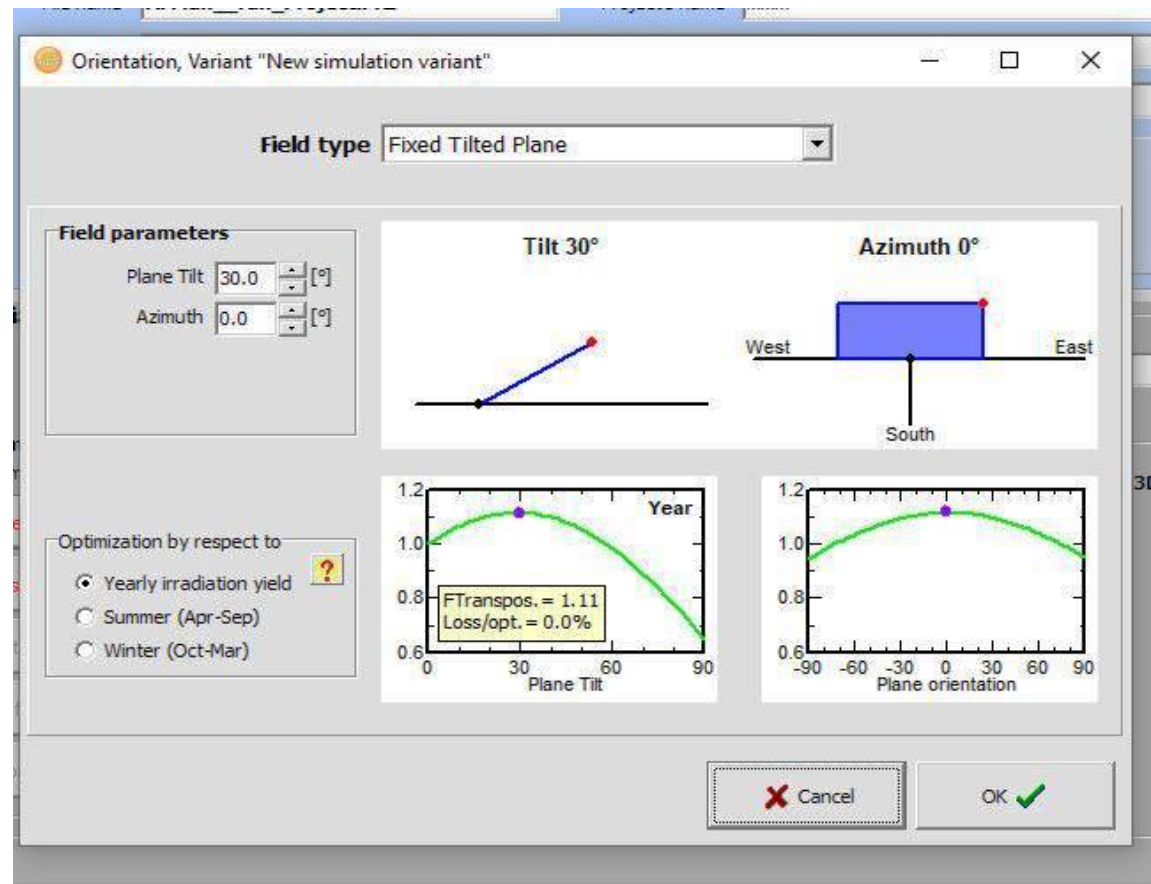

Fig.5. The best position of PV.

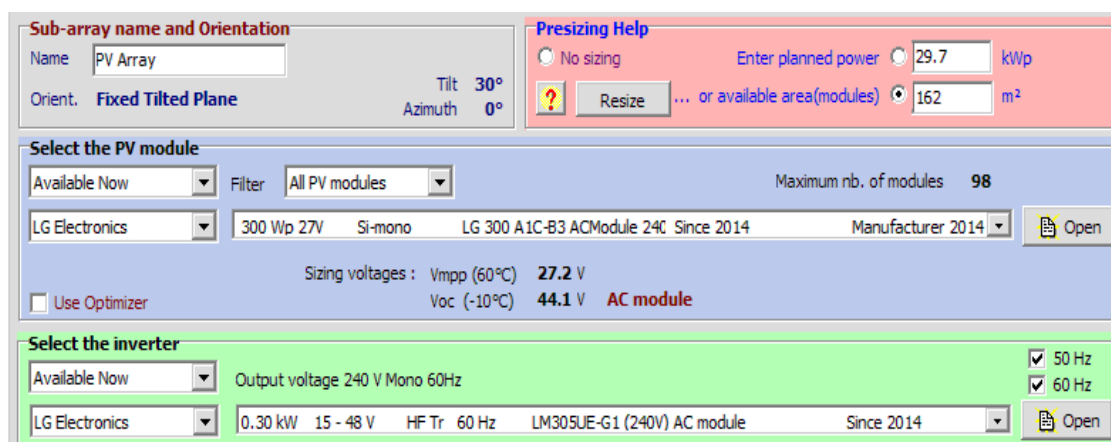

Fig.6. Selecting available area, PV model and inverter through Design Builder for PV syst. program

\section{RESULTS \& DISCUSSION}

The previous retrofits were applied on the three cases in Design builder software and the following results were obtained. 


\subsection{Optimal design of cooling system for case (3)}

As shown in [Fig.7], the less energy consumption cooling systems are:( Water cooled chiller, Mechanical ventilation with heat recovery and Nat vent no heating or cooling). It is considered that the best option in the previous systems is Nat vent because it is not costly and also the least discomfort hours are in summer months as shown [Figure-8]. Despite that, air does not reach all parts of each room as shown in [Figure-9]; so that a mechanical ventilation must be used. From previous reasons, the optimal design which achieve the least discomfort hours and less cost will be chosen, so the optimal design is Nat vent mechanical ventilation theat recovery. The required area for fan coil unit on roof is $80 \mathrm{~m} 2$ for this building.[12]

\subsection{Solar gains}

As shown in [Figure-10], total solar gains for case (1) decreased by $61 \%$, case (2) by $46 \%$ and case (3) by $72 \%$.

\subsection{Energy consumption}

[Fig.11] shows that, the total energy consumption decreases by $81 \%$ for case (1), 50\% for case (2) and $91 \%$ for case (3).

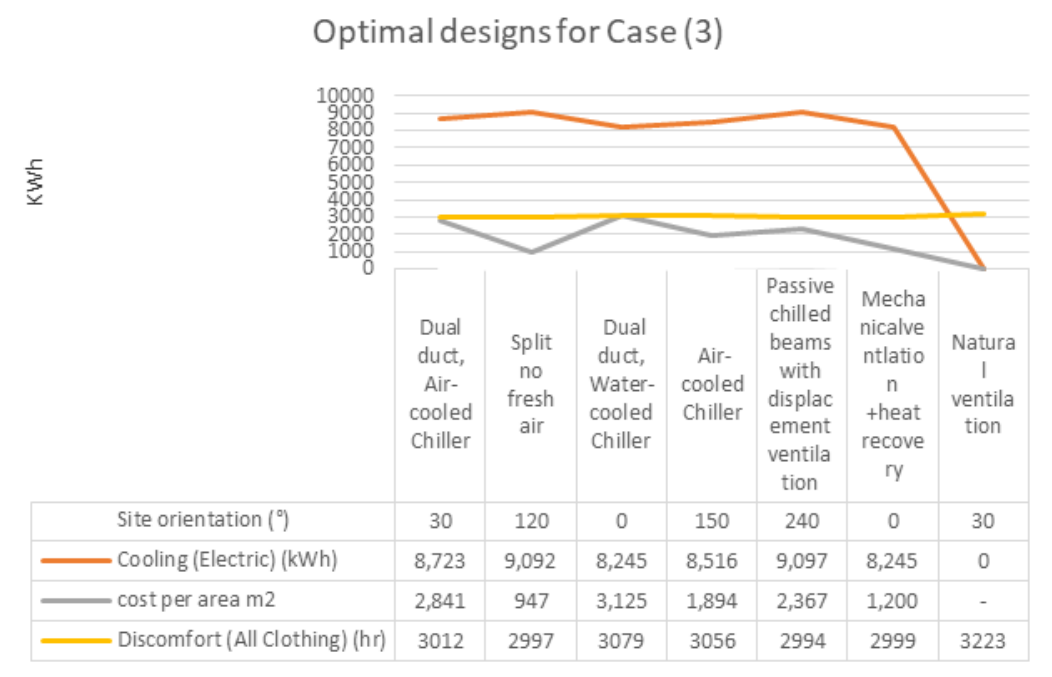

Fig.7. Optimization results for case (3). 


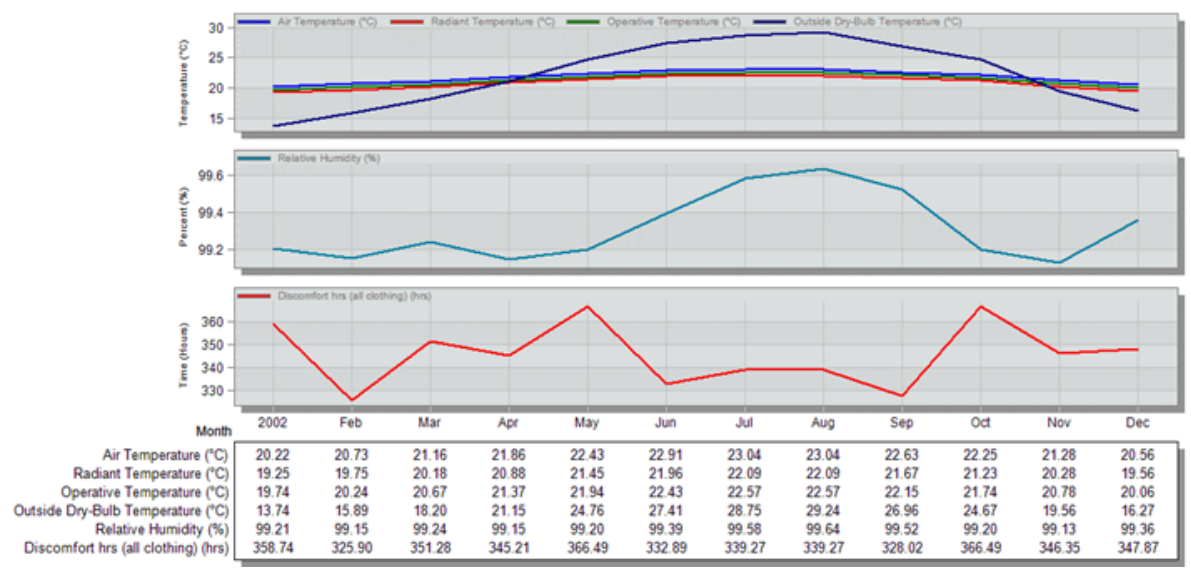

Fig.8. Results of monthly discomfort hours for Nat Vent.

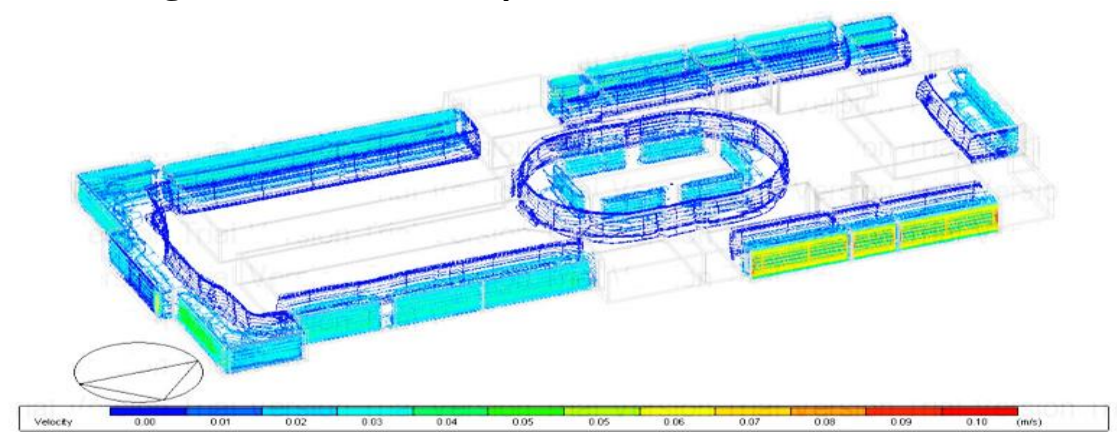

Fig.9. Results of air velocity for Nat vent.

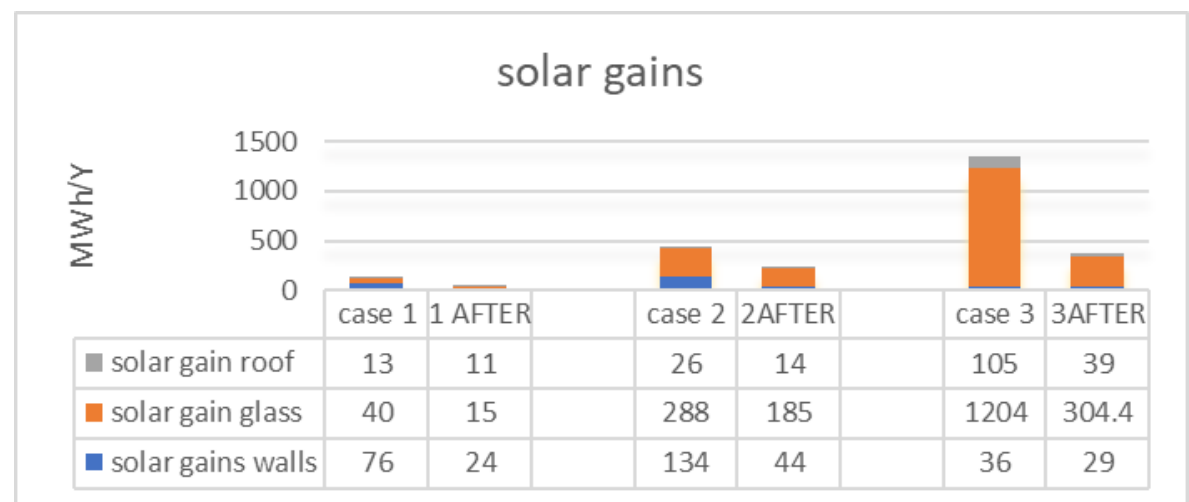

Fig.10. Solar gains for case studies after applying retrofits.

\subsection{Renewable energy}

The results of adding PV solar cells are shown in table (7). To achieve zero energy for case (2), the electricity surplus generated from case (1) and case (3) will be transferred to case (3). See Table (7). There will be 254 PV cells that 
will be installed on the roof of case (1). Case (1) will use only 18 and the excess will generate electricity for case (2). Also, $304 \mathrm{PV}$ cells will be installed on the roof of case (3) where case (3) will use only (200) and the excess will generate electricity for case (2) in addition to the $98 \mathrm{PV}$ cells that is installed on the roof of case (2).

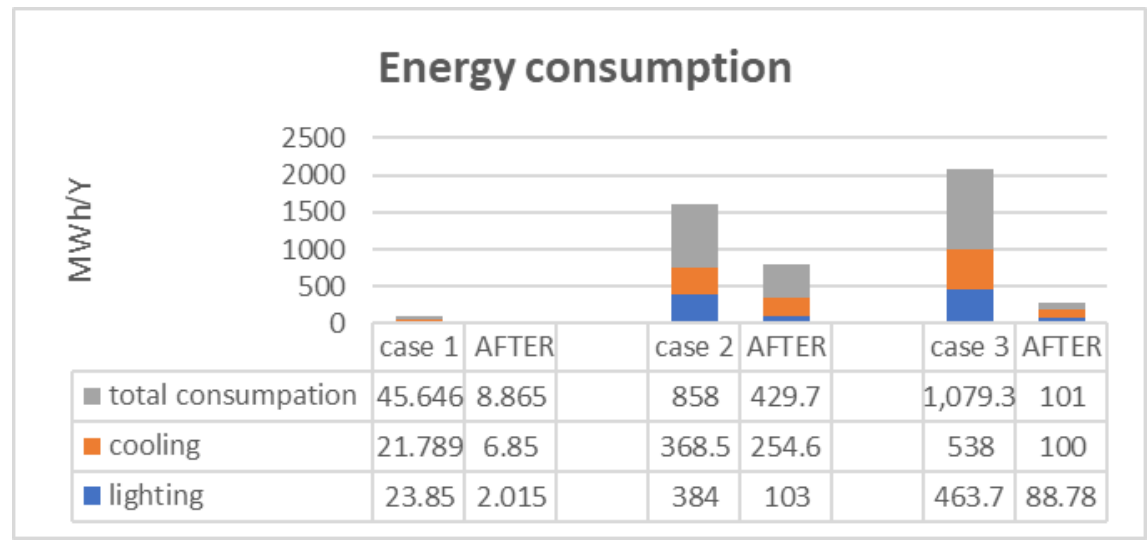

Fig.11. Energy consumption for case studies.

Table.7. Summary of adding Renewable Energy for the three cases.

\begin{tabular}{|c|c|c|c|}
\hline & Case 1 & Case 2 & Case3 \\
\hline $\begin{array}{l}\text { Available area } \\
\text { on roof }\end{array}$ & & $=[5$ & \\
\hline $\begin{array}{c}\text { Available for } \\
\text { solar cells }\end{array}$ & Area $=417 \mathrm{~m} 2$ & Area $=162 \mathrm{~m} 2$ & Area $=500 \mathrm{~m} 2$ \\
\hline $\begin{array}{l}\text { Electricity } \\
\text { needed to } \\
\text { achieve ZEB }\end{array}$ & $8.865 \mathrm{MWh} /$ year & $\begin{array}{c}429.7 \\
\text { MWh/year }\end{array}$ & 101.3 MWh/year \\
\hline $\begin{array}{l}\text { Total number of } \\
\text { PV modules }\end{array}$ & 254 modules & 98 modules & 304 modules \\
\hline $\begin{array}{c}\text { Energy } \\
\text { produced from } \\
\text { PV }\end{array}$ & $129.4 \mathrm{MWh} /$ year & $\begin{array}{c}50.11 \\
\mathrm{MWh} / \text { year }\end{array}$ & 154.7MWh/year \\
\hline
\end{tabular}

It is clear from the results (relation between the electrical energy produced by the building and its consumption), case (1) achieve net ZEB, case (3) is nearly to achieve net ZEB and case (2) does not achieve as shown in Table (8) and [Fig.12]. 
Table.8 Consumed and produced energy for each case

\begin{tabular}{|c|c|c|c|}
\hline & Case1 & Case2 & Case 3 \\
\hline Demand & $8.865 \mathrm{MWh} /$ year & $\begin{array}{c}429.7 \\
\text { MWh/year }\end{array}$ & $\begin{array}{c}101.3 \\
\text { MWh/year }\end{array}$ \\
\hline Supply & $8.865 \mathrm{MWh} /$ year & $\begin{array}{c}224.045 \\
\text { MWh/year }\end{array}$ & $\begin{array}{c}101.3 \\
\text { MWh/year }\end{array}$ \\
\hline Number of PV model & 18 & $\begin{array}{c}(254-18) \\
+(304-200) \\
+98=438\end{array}$ & 200 \\
\hline $\begin{array}{c}\text { Percentage of total energy } \\
\text { decrease }\end{array}$ & 100 & 48 & 100 \\
\hline \multicolumn{2}{|l}{} \\
\hline
\end{tabular}

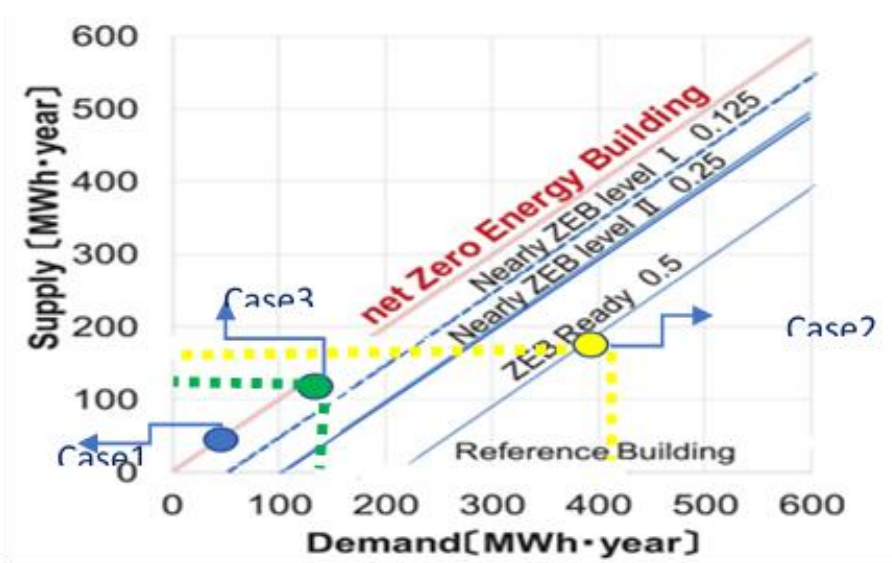

Fig.12. Energy consumed and produced from buildings. [Source (researcher)]

\subsection{Cost}

To calculate pay back value of retrofitting, we should calculate the annual cost of total consumption before upgrading. The last change in monthly tariffs (2019/2020) for residential and commercial sectors will be as follows (If the consumption is more than $1000 \mathrm{~kW}$ ( $\mathrm{kWh} /$ month), the price is 1.45 pound) Electricity consumption tariff values for 2018/2019).[16] Pay pack value = Cost of electricity before upgrading / total cost of upgrading. The officially exchange rate for $\$ 1=15.80$ EGP. Table (9) shows the cost of retrofitting and back value for each case 
JES, Assiut University, Faculty of Engineering, Vol. 48, No. 4, July 2020, pp. 633-648

Table.9. cost of retrofitting and back value

\begin{tabular}{|c|c|c|c|}
\hline $\begin{array}{c}\text { Cost per } \\
\text { surface } \\
\text { area (EGP) }\end{array}$ & Case 1 & Case2 & Case 3 \\
\hline $\begin{array}{c}\text { LIFGHTIN } \\
\text { G }\end{array}$ & 634,323 & $10,109,905$ & $8,307,656.4$ \\
\hline Cooling & 318,812 & ------- & $2,094,060$ \\
\hline Insulation & 96750 & 536,411 & $552,513.2$ \\
\hline windows & 211,145 & $1,814,736.95$ & $5,372,459.45$ \\
\hline PV & $18 * 2700=48600$ & $438 * 2700=1,182,600$ & $\begin{array}{c}304 * 2700= \\
820800\end{array}$ \\
\hline Total cost & $1,309,630$ & $13,643,652.95$ & $17,147,489.05$ \\
\hline Pay pack & $\begin{array}{c}1,309,630 / 45646 * 1.45=15 \\
\text { value }\end{array}$ & $\begin{array}{c}13,643,652.95 / 857.7 * 103 * 1 \\
.45= \\
11 \text { year }\end{array}$ & $\begin{array}{c}17,147,489.05 \\
/ \\
1079 * 103 * 1.4 \\
5= \\
11 y e a r\end{array}$ \\
\hline
\end{tabular}

\section{Conclusions}

Retrofitting existing building is still feasible to be ZEB depending on size of building and its old design, each design case has its own special characteristics that should be well analyzed using simulation software.

Case (1) is simple one floor building, so can be achieved ZEB. Despite using excessed electricity from Case (1) and Case (3), Case (2) achieved only 50\% of its consumption for many reasons :first, its pitched roof which can't be used fully for PV cells, second the cooling system can't be changed, Finally reason it has more than thirty educational space And that consumes more electricity . Despite, Case (3) is similar in floor number with case (2), it achieves ZEB because we were able to select the optimum cooling system, this building has flat roof helped us to produce renewable energy enough for consumption. The possibility of achieving ZEB or nearly ZEB building in universities is greater. It is often more cost effective and efficient to generate Renewable Energy such as solar energy through PV cells in a central location on the campus or in the community, rather than on (or in addition to) each building. 


\section{References}

[1] European Commission., Directive 20/31/EC of the European Parliament and of the Council of 19 May 2010 on the energy performance of buildings (recast), Official Journal of the European Communities, 13-35, (2010).

[2] new.usgbc.org/leed-zero.

[3] Torcellini, P., Pless, S., Deru, M., \& Crawley, D., Zero energy buildings: A critical look at the definition. National Renewable Energy Laboratory and Department of Energy, US, (2006).

[4] Ibrahim, A., Renewable energy sources in the Egyptian electricity market: A review, Renewable and Sustainable Energy Reviews, 16(1), 216-230, (2012).

[5] Reda, F., Tuominen, P., Hedman, Å., \& Ibrahim, M. G. E., Low-energy residential buildings in New Borg El Arab: Simulation and survey-based energy assessment, Energy and Buildings, 93, 65-82, (2015).

[6] Albadry, S., Feasibility of converting existing residential buildings to net zeroenergy buildings in Egypt, Master's thesis, AUC, (2016).

[7] Abolsaad,S, Zero Energy Residential Buildings as an Approach for Sustainable Urban Development in the Egyptian Desert, Master's thesis, Mansoura University, (2018).

[8] Samaan, M. M., Farag, O., \& Khalil, M., Using simulation tools for optimizing cooling loads and daylighting levels in Egyptian campus buildings, HBRC journal, 14(1), 79-92, (2018).

[9] Yoshida, Y., Shimoda, Y., \& Ohashi, T. (2017). Strategies for a sustainable campus in Osaka University. Energy and buildings, 147, 1-8.

[10] https://www.bca.gov.sg/zeb/whatiszeb.html.

[11] Egyptian code for specifications of thermal insulation works items 2008.

[12] Lechner, N., Heating, cooling, lighting: Sustainable design methods for architects, John wiley \& sons (2014).

[13] Garde, F., Ayoub, J., Aelenei, L., Aelenei, D., \& Scognamiglio, A. (Eds.)., Solution Sets for Net Zero Energy Buildings: Feedback from 30 Buildings Worldwide, John Wiley \& Sons, (2017).

[14] Hootman, T., Net zero energy design: a guide for commercial architecture, John Wiley \& Sons, (2012).

[15] http://www.solarmarketegypt.com.

[16] http://egyptera.org/ar/t3reefa.aspx. 


\section{نحو مباني صفرية الطاقة في جامعة المنصورة}

هذا البحث يقدم ويستعرض بحالة در اسية تطبيق مبدأ المباني صفرية الطاقة على مباني التعليم الجامعي في مصر وذلك بلرر اسة ثلاثة مباني تابعة لكلية الهندسةجامعة المنصورة (مبنيين قائمين ومبنى تحت الانشاء) وذلك باستخدام برنامج Design Builder ذلك من خلال در اسة استهلاك الطاقة لكل مبنى ثم تقديم مقترح للتعديل. كما تم ايضـا استخدام ادوات المحاكاة (Simulation tools for optimizing) لاختيار أفضل نظام تبريد للمبنى الذي تحت الانشاء. ويتضح من خلال النتائج ان التعديلات يمكن ان توفر في استهلاك الطاقة من 50-90 \% مع امكانية تحقيق صفرية الطاقة بإستخدام مصسادر الطاقة المتجددة منثل الخلايا الثمسية. 